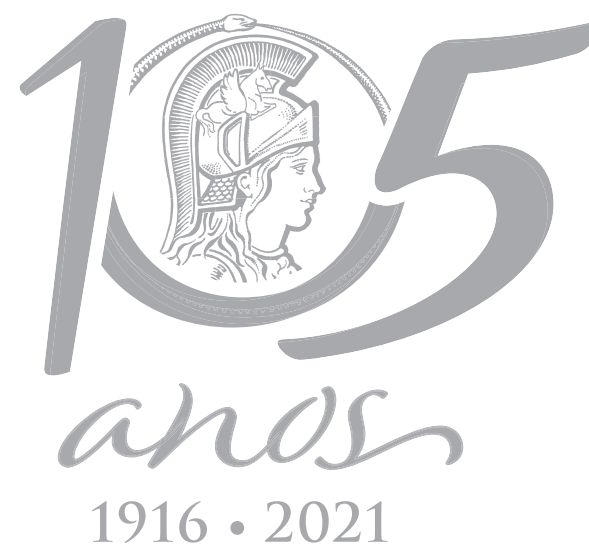

\title{
ECOSYSTEMS
}

\section{New species of Filaria (Nematoda: Filariidae) in the Lesser Grison Galictis cuja (Molina) (Carnivora: Mustelidae) from northern Patagonia, Argentina and comments about the South American species of the genus}

\author{
ESTEFANÍA BAGNATO, ROMINA L. D'AGOSTINO, DANIEL E. UDRIZAR SAUTHIER \& \\ MARÍA C. DIGIANI
}

\begin{abstract}
Filaria lorenzo n. sp. is described in the Lesser Grison, Galictis cuja from northern Patagonia, Argentina. The new species can be differentiated from the eight species of Filaria from the Old World by the shape of the sclerotized preesophageal ring. The four remaining species of the genus parasitize American Mephitidae and/or Mustelidae. Filaria carvalhoi from Brazil and F. texensis from USA lack a preesophageal ring, whereas F. taxideae from USA and F. conepati from Argentina share with our specimens a preesophageal ring mostly mushroom shaped. Our specimens differ from F. taxideae by lacking lateral alae, by a different ornamentation of the female tail and by the male lacking adcloacal papillae. The new species also differs from F. conepati by the shape of the preesophageal ring and by the shape of the eggs. The indirect examination of the types of F. conepati and F. carvalhoi, corroborated the existence of differences between these two species, allowing us to refute their synonymy, as proposed by some authors. Our results extend the taxonomy of Filaria to 13 species and comprise the first report of a filarioid nematode for an Argentinean mustelid, and the first report for Patagonia.
\end{abstract}

Key words: Argentina, Filaria, Lesser Grison, Mustelidae, Patagonia, parasites.

\section{INTRODUCTION}

The Lesser Grison, Galictis cuja (Molina) (Carnivora: Mustelidae) is distributed from southern Peru, western Bolivia and E and S Brazil to Paraguay, Uruguay, Argentina and central and southern Chile (Yensen \& Tarifa 2003). In Argentina, it reaches the southern end of Santa Cruz province (Prevosti \& Travaini 2005, Chébez et al. 2014). The Lesser Grison occupies a wide variety of habitats, including shrub and herbaceous steppes, pastures, scrublands, savannahs, open forests, forests and humid forests and marine coasts from the sea level up to 4200 masl (Larivière \& Jennings 2009).

Helminthes parasites of the Lesser Grison reported from Argentina are very scarce: only Aonchotheca putorii (Rudolphi, 1819) LópezNeyra 1947 (Nematoda: Capillariidae) from Entre Ríos province (Moleón et al. 2015) was recorded. Other parasites from this host were reported in Paraguay and Brazil: the digenean Platynosomum illiciens (Braun, 1901) (Dicrocoeliidae), the nematodes Dioctophyme renale (Goeze, 1782) (Dioctophymatidae), Molineus elegans (Travassos, 1921) (Trichostrongylidae), Physaloptera sp. (Physalopteridae), 
Strongyloides sp. (Strongyloididae), Lagochilascaris sp. (Ascaridae), Gnathostoma sp. (Gnathostomatidae), Cruzia sp. (Kathlaniidae), Dirofilaria sp. (Onchocercidae), Crenosoma brasiliense Vieira, Pereira, Lima, Neto, Gonçalves \& Luque, 2012 (Metastrongylidae), Oxyuridae gen. et sp., Trichostrongylidae gen. et sp. and the acanthocephalan Pachysentis gethi (Machado, 1950) (Oligacanthorhynchidae) (Vieira et al. 2008, Corrêa et al. 2016).

The genus Filaria Mueller, 1787 includes large parasites of subcutaneous tissues of mammals. The taxonomy of this nematode has been subjected to disputes among parasitologists with several species of Filaria reported from different host species (Otranto et al. 2007). Filaria martis Gmelin, 1790 was fixed by Stiles (1907) as the type-species, and the genus comprises at present 12 valid species (Table I), of which the last four were described by Chabaud \& Mohammad (1989).

In South America, Filaria patersoni Mazza, 1928 was reported from Argentina but it was then transferred to Litomosoides Chandler, 1931 by Chitwood (1933). This species is a parasite of the peritoneal cavity of Holochilus brasiliensis Desmarest (Rodentia: Cricetidae) (Mazza 1928, Chitwood 1933, Gomes et al. 2003) and was recently redescribed by Notarnicola et al. (2010). Filaria kitti Seldmeier, 1931 was reported, without an adequate description, from the rodent Myocastor coypus (Molina) imported into Europe probably of Argentinean origin. The original description of the parasite was barely enlarged by Grieder $(1937,1938)$ but there are no accompanying illustrations and no reference to type material is made. Filaria serpicula Molin, 1858 was described from Brazil in Carollia brevicauda Wied-Neuwied (=Phyllostoma brevicaudum), and Sturnira lilium Geoffroy (=Phyllostoma spiculatum) (Chiroptera: Phyllostomidae) but it was transferred by Guerrero et al. (2002) to the genus Litomosoides (Molin 1858, Guerrero et al. 2002). Filaria conepati Schuurmans-Stekhoven, 1952 was described in Conepatus chinga (Molina) (Carnivora: Mephitidae) from Formosa province in Argentina (Schuurmans-Stekhoven 1952) although it was later considered by some authors as a synonym of Filaria carvalhoi Freitas \& Lent, 1937, a species described in the same host from Brazil (Anderson 1960, Chabaud \& Mohammad 1989).

In this paper we describe a new species of Filaria from the subcutaneous tissue of Galictis cuja from Patagonia using light and scanning electron microscopy. In addition, the taxonomy of $F$. conepati and F. carvalhoi is clarified by reexamining the original type specimens.

\section{MATERIALS AND METHODS}

Four specimens of Lesser Grison road-killed were collected, dissected and examined for helminths: two males near the city of Sierra Grande on National Route $N^{\circ} 3$ (41 29.3'S; 65 $21.2^{\prime} \mathrm{W}$ ), Río Negro province; and two females from Provincial Route $\mathrm{N}^{\circ} 2$ between El Desempeño and Istmo Ameghino (42 $28.5^{\prime} \mathrm{S} ; 64^{\circ} 41.4^{\prime} \mathrm{W}$ ), Chubut province, Argentina. The corpses were kept frozen and then necropsied. The skin of the specimens was completely removed and the nematodes found in the subcutaneous tissues were removed. Some nematodes were fixed in $4 \%$ formalin/distillated water and preserved and stored in $70 \%$ ethanol. Specimens designated for morphological study were cleared in lactoglycerol for examination under light microscope (Leica DM500 and/or Leica DM2500) (Leica, Wetzlar, Germany). Measurements of body length, given in millimeters $(\mathrm{mm})$, were taken under a stereoscope microscope (Leica Wild M3Z with drawing attachment Wild 308700). Other measurements (as range, followed by 
Table I. Species of Filaria, their hosts (Order: Family), site of infection and geographical distribution.

\begin{tabular}{|c|c|c|c|c|}
\hline Species & Hosts & Site & Distribution & References \\
\hline $\begin{array}{l}\text { Filaria martis Gmelin, } \\
1790\end{array}$ & $\begin{array}{l}\text { Carnivora: } \\
\text { Mustelidae, } \\
\text { Felidae }\end{array}$ & ST & $\begin{array}{l}\text { Europe, } \\
\text { Africa, } \\
\text { Mexico }\end{array}$ & $\begin{array}{l}\text { Caballero (1948); Anderson (1960); Tadros } \\
\text { (1964); Chabaud \& Mohammad (1989); } \\
\text { Otranto et al. (2007); Torres et al. (2016) }\end{array}$ \\
\hline $\begin{array}{l}\text { Filaria carvalhoi Freitas } \\
\text { \& Lent, } 1937\end{array}$ & $\begin{array}{l}\text { Carnivora: } \\
\text { Mephitidae }\end{array}$ & ST & Brazil & $\begin{array}{l}\text { Freitas and Lent (1937); Chandler (1947); } \\
\quad \text { Chabaud \& Mohammad (1989) }\end{array}$ \\
\hline $\begin{array}{c}\text { Filaria hyracis (Ortlepp, } \\
\text { 1937) }\end{array}$ & $\begin{array}{l}\text { Hyracoidea: } \\
\text { Procaviidae }\end{array}$ & $\begin{array}{l}\text { SM and } \\
\quad F\end{array}$ & South Africa & $\begin{array}{l}\text { Ortlepp (1937); Chabaud and Rousselot } \\
\text { (1956); Chabaud \& Mohammad (1989) }\end{array}$ \\
\hline $\begin{array}{l}\text { Filaria texensis Chandler, } \\
\qquad 1947\end{array}$ & $\begin{array}{l}\text { Carnivora: } \\
\text { Mephitidae }\end{array}$ & S & USA & $\begin{array}{c}\text { Chandler (1947); Chabaud \& Mohammad } \\
\text { (1989) }\end{array}$ \\
\hline $\begin{array}{c}\text { Filaria conepati } \\
\text { Schuurmans-Stekhoven, } \\
1952\end{array}$ & $\begin{array}{l}\text { Carnivora: } \\
\text { Mephitidae }\end{array}$ & $N, E$ & Argentina & $\begin{array}{c}\text { Schuurmans-Stekhoven (1952); Chabaud } \\
\text { \& Mohammad (1989) }\end{array}$ \\
\hline $\begin{array}{l}\text { Filaria cephalophi } \\
\text { Chabaud \& Rousselot, } \\
1956\end{array}$ & $\begin{array}{l}\text { Cetartiodactyla: } \\
\text { Bovidae }\end{array}$ & ST & $\begin{array}{l}\text { Gabonese } \\
\text { Republic }\end{array}$ & $\begin{array}{c}\text { Chabaud and Rousselot (1956); Chabaud } \\
\text { et al. (1978); Chabaud \& Mohammad } \\
\text { (1989) }\end{array}$ \\
\hline $\begin{array}{l}\text { Filaria russelli Tadros, } \\
1964\end{array}$ & $\begin{array}{l}\text { Carnivora: } \\
\text { Felidae }\end{array}$ & ST & Kenya & $\begin{array}{c}\text { Tadros (1964); Chabaud \& Mohammad } \\
\text { (1989) }\end{array}$ \\
\hline $\begin{array}{l}\text { Filaria taxideae Keppner, } \\
1969\end{array}$ & $\begin{array}{l}\text { Carnivora: } \\
\text { Mustelidae, } \\
\text { Mephitidae }\end{array}$ & ST & USA & $\begin{array}{c}\text { Keppner (1969); Chabaud \& Mohammad } \\
\text { (1989) }\end{array}$ \\
\hline $\begin{array}{c}\text { Filaria bakerhugoti } \\
\text { Chabaud \& Mohammad, } \\
1989\end{array}$ & $\begin{array}{l}\text { Rodentia: } \\
\text { Hystricidae }\end{array}$ & ST & South Africa & Chabaud \& Mohammad (1989) \\
\hline $\begin{array}{l}\text { Filaria latala Chabaud \& } \\
\text { Mohammad, } 1989\end{array}$ & $\begin{array}{l}\text { Carnivora: } \\
\text { Felidae }\end{array}$ & NM & South Africa & Chabaud \& Mohammad (1989) \\
\hline $\begin{array}{l}\text { Filaria melis Chabaud \& } \\
\text { Mohammad, } 1989\end{array}$ & $\begin{array}{l}\text { Carnivora: } \\
\text { Mustelidae }\end{array}$ & ST & Irak & Chabaud \& Mohammad (1989) \\
\hline $\begin{array}{c}\text { Filaria versterae } \\
\text { Chabaud \& Mohammad, } \\
1989\end{array}$ & $\begin{array}{l}\text { Rodentia: } \\
\text { Pedetidae }\end{array}$ & NM & South Africa & Chabaud \& Mohammad (1989) \\
\hline Filaria lorenzo n. sp. & $\begin{array}{l}\text { Carnivora: } \\
\text { Mustelidae }\end{array}$ & ST & Argentina & This study \\
\hline
\end{tabular}

Abbreviations: E, ear; F, fascia; N, neck; NM, not mentioned; S, skin; SM, superficial muscle; ST, subcutaneous tissues.

mean in parentheses) are given in micrometers $(\mu \mathrm{m})$ and were calculated with software of Leica DM500. Photographs of mounted specimens were taken with a Leica ICC50W camera with software connected to the microscope. specimens intended for scanning electron microscopy study (SEM) were dehydrated in ethanol, dried by the critical point technique, coated with gold and examined in a Jeol 6360 LV microscope (Jeol, Tokyo, Japan). Photographs of the type material of Filaria conepati were requested to the Helminthological Collection 
of the Instituto de Invertebrados, Fundación Miguel Lillo (FML-II), Tucumán province, Argentina (FML- 6/VIII/47-Lote 202). Photographs of the type material of Filaria carvalhoi were requested to the Helminthological Collection of Instituto Oswaldo Cruz (CHIOC), Rio de Janeiro, Brazil (CHIOC 9511 a-d, 9512 paratypes). Type specimens of Filaria lorenzo n. sp. were deposited in the Helminthological Collection of the Museo de La Plata (MLP-He), La Plata, Argentina. Host specimens were deposited in the Colección Ecológica de Vertebrados de Ecosistemas Continentales (CEVEC) of the Instituto Patagónico para el Estudio de los Ecosistemas Continentales- CONICET, Puerto Madryn, Chubut province. The classification of the nematodes above the genus level follows Anderson \& Bain (1977) and Gibbons (2010).

\section{RESULTS}

Superfamily Filarioidea Weinland, 1858

Family Filariidae (Weinland, 1858) Cobbold, 1879

\section{Subfamily Filariinae Weinland, 1858 \\ Genus Filaria Mueller, 1787 \\ Description \\ Filaria lorenzo n. sp. (Figs. 1-2)}

Based on 2 entire males and 4 broken females from Río Negro province, plus 1 entire female from Península Valdés, Chubut province.

General. Adult specimens whitish in life. Body long and slender, anterior end blunt. Lateral alae absent. Anterior end with four submedian cephalic papillae, two amphids and four small internal labial papillae surrounding the mouth (Figs. 1a, 2a). Buccal cavity reduced, tubular with thin walls, surrounded at base by thick, refractory preesophageal ring, mushroom shaped, embedded in anterior end of muscular esophagus (Figs. 1b, 1g). Esophagus divided into short anterior muscular part and long glandular part; junction between two parts often not discerned. Deirids spinous, close to anterior extremity.

Male holotype. Body length $65.5 \mathrm{~mm}$. Maximum width 302. Muscular part of esophagus 570 long by 76 wide; glandular part more than 1,222 long by 112 wide, posterior end indistinct. Preesophageal ring 22 long by 23 wide (Fig. 1g). Nerve ring 102, deirids 162 from anterior end (Fig. 1g). Excretory pore not discerned. Posterior extremity somewhat attenuated with long and narrow caudal alae. Caudal alae 4,055 long by 37 wide (Fig. 1i). Cloacal opening 221 from posterior end. Eight pairs caudal papillae. Two pairs precloacal, six pairs postcloacal (Fig. 1i). Phasmids not observed. Spicules markedly dissimilar in size and morphology. Right spicule 134 long, curved ventrally (Fig. 1h). Left spicule 696 long, consisting of long tubular calomus, 314 long by 13 wide, and broad, membranous lamina; lamina 316 long, 8 wide; membrane 194 long by 26 maximum wide (Fig. 1j). Gubernaculum present (Figs. 1h, 1i).

Male paratype $(n=1)$. Body length $68 \mathrm{~mm}$. Maximum width 331. Muscular and glandular parts of esophagus not discerned. Preesophageal ring 26 long by 24 wide. Nerve ring 68, deirids 123 from anterior end. Excretory pore not discerned. Caudal alae 5,552 long by 46 wide (Fig. 1i). Cloacal opening 137 from posterior end. Right spicule 147 long, curved ventrally. Left spicule 570 long, calomus 238 long by 17 wide, and broad, membranous lamina; lamina 316 long, 6 wide; membrane 252 long by 24 maximum wide. Gubernaculum present.

Female ( $n=4$, broken at different levels. Four proximal fragments $118-152 \mathrm{~mm}$ in length, maximum width 404-440 (421). Muscular part of esophagus 651-907 (820, n=4) long by 44-121 $(75, n=4)$ wide; glandular part 1,490-2,109 $(n=2)$ long by 95-195 (150, $\mathrm{n}=4)$ wide, posterior end 


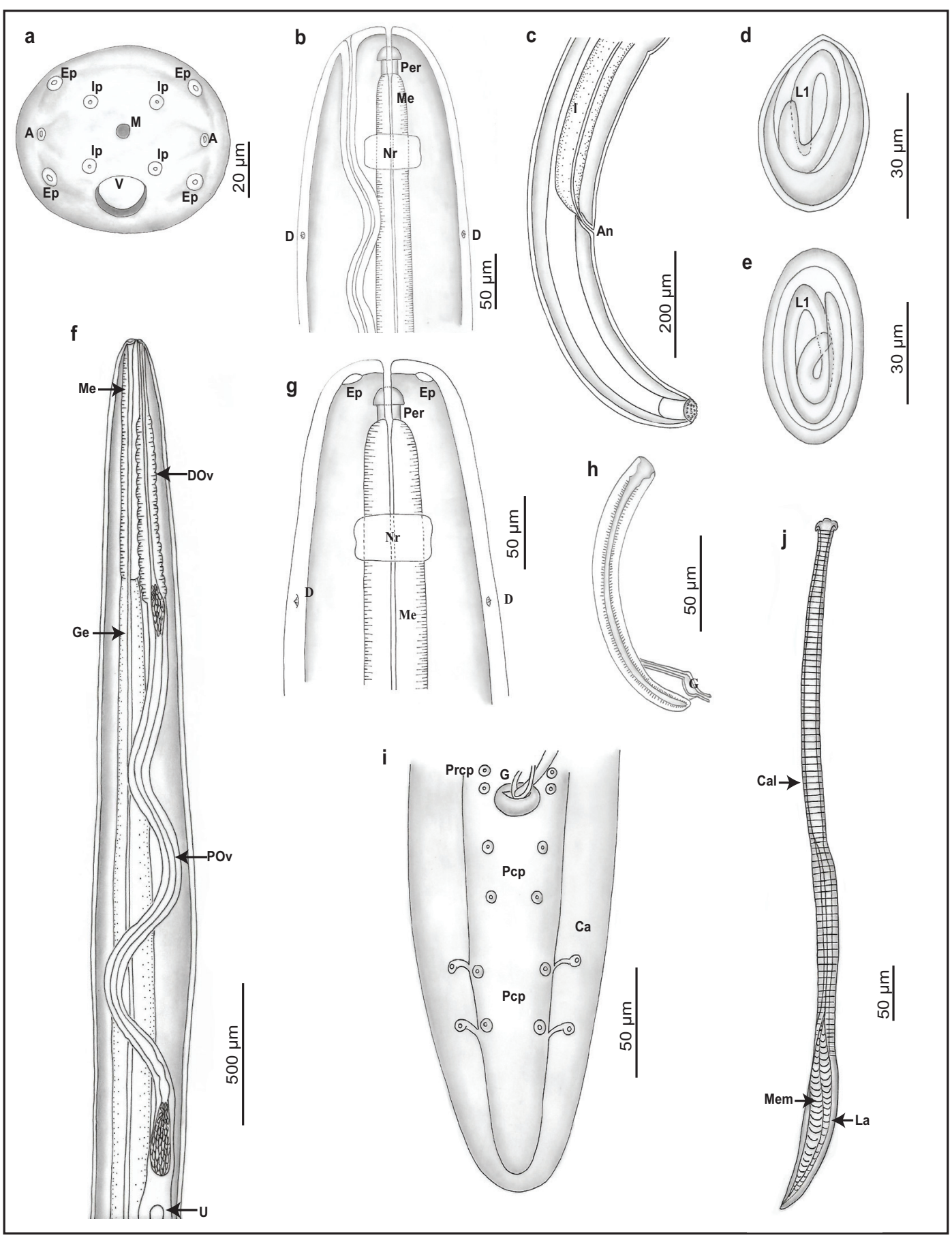

Figure 1. Line drawings of Filaria lorenzo n. sp. (Nematoda: Filariidae) in the Lesser Grison Galictis cuja (Molina) from Patagonia, Argentina. Scale values are given beside each bar. (a) Female head, apical view. (b) Detail of anterior end of female, left lateral view. (c) Posterior end of female, right lateral view. (d) Embryonated egg in uterus. (e) Embryonated egg in ovejector. (f) Anterior end of female, right lateral view. (g) Detail of anterior end of male, ventral view. (h) Right spicule, lateral view. (i) Posterior end of male, ventral view. (j) Left spicule, lateral view. Abbreviations: A, amphid; An, anus; Ca, caudal ala; Cal, calomus; D, deirid; DOv, distal ovejector; Ep, external papilla (cephalic); G, gubernaculum; Ge, glandular esophagus; I, intestine; Ip, internal papilla (labial); L1, First stage larva; La, lamina; M, mouth; Me, muscular esophagus; Mem, membrane; Nr, nerve ring; Per, pre-esophageal ring; POv, proximal ovejector; Prcp, pre-cloacal papillae; Pcp, post-cloacal papillae; U, uterus; V, vulva. 


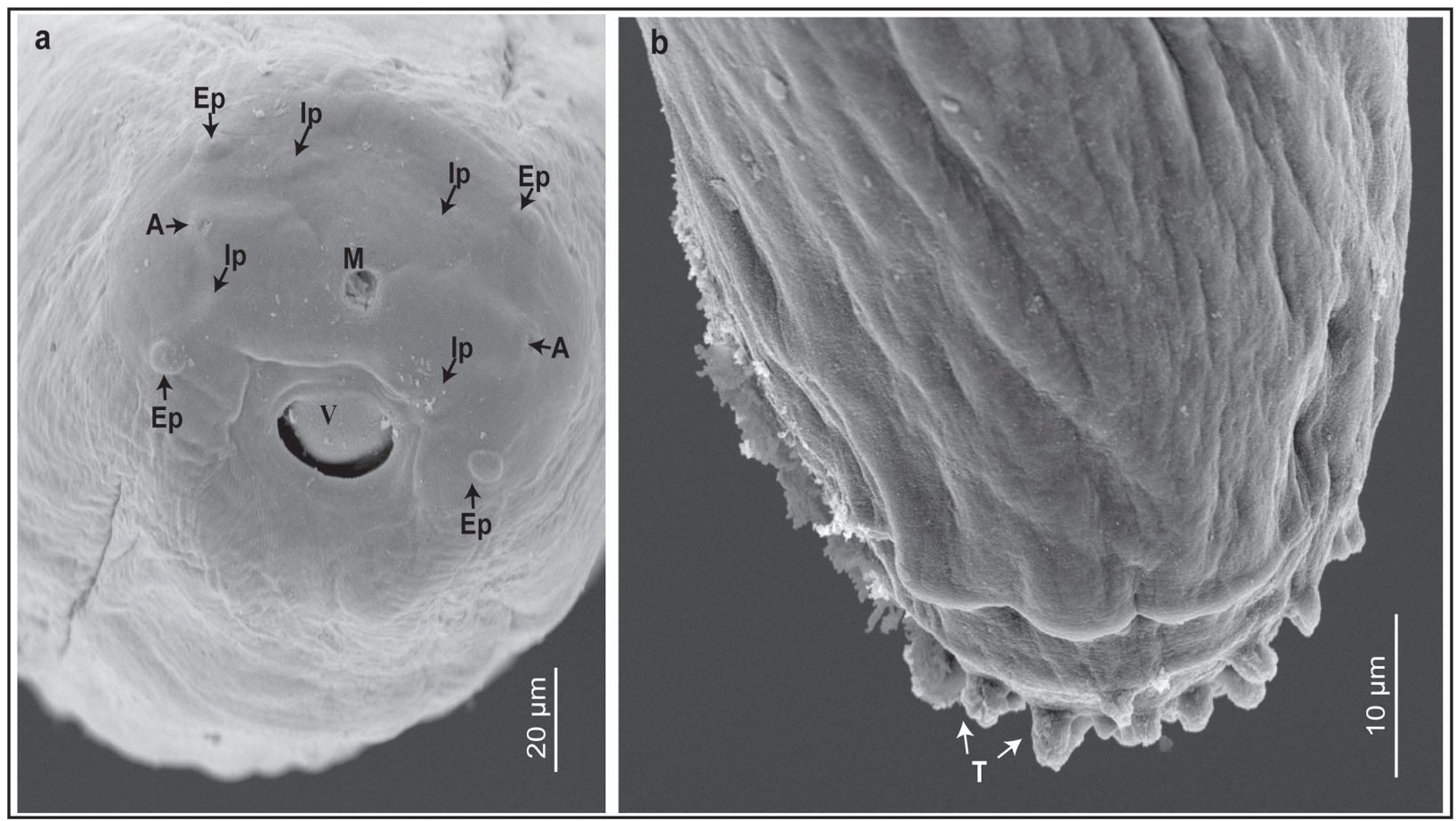

Figure 2. Scanning electron micrographs of Filaria lorenzo n. sp. (Nematoda: Filariidae) in the Lesser Grison Galictis cuja (Molina) from Patagonia, Argentina. Scale values are given beside each bar. (a) Female head, subapical view. (b) Posterior end of female, detail of tubercles. Abbreviations: A, amphid; Ep, external papilla (cephalic); Ip, internal papilla (labial); M, mouth; T, tubercles; V, vulva.

indistinct. Preesophageal ring 20-27 (24, n=3) long by 22-23 (22, $n=3$ ) wide (Fig. 1b). Nerve ring 81-108 (92, n=4), and deirids 139-211 (178, n=3) respectively from anterior end. Excretory pore not discerned. Vulva subapical, just ventral to oral opening. Ovejector 1,805-3,171 (2,556, n=4) long, divided into two distinct parts. Distal ovejector with strong muscular walls and lined with cuticle, 795-851 (811, n=4) long, its diameter decreasing gradually to the apex in the last 250-300 micrometers. Proximal ovejector longer 1,007-2,319 (1,745, n=4) long, passing into a short chamber and then into a didelphic uterus (Fig. 1f). Eggs 38-56 (47) long by 21-39 (31) wide ( $n=19)$ with first larval stage inside (Figs. 1d; in uterus $1 \mathrm{e}$; in ovejector). Two distal fragments 142, 86 in length, maximum width 423, 364. Tail 322 , 484 long, with blunt end bearing apically 15-20 small rounded tubercles (Fig. 1c). Phasmids not observed.
Female ( $n=1$, whole specimen from Chubut province). Body length $116 \mathrm{~mm}$. Maximum width 327. Muscular part of esophagus 728 long by 59 wide; glandular part more than 1,500 long by 155 wide, posterior end indistinct. Preesophageal ring 21 long by 23 wide. Nerve ring and deirids 95 and 99 from anterior end, respectively. Excretory pore not discerned. Ovejector 2,096 long, distal part 799 long, proximal part 1,296 long. Eggs 3647 (42) long by 18-28 (23) wide ( $n=14)$. Tail 308 long, with 18 small rounded tubercles. Phasmids not observed.

\section{Taxonomic summary}

Type host: Galictis cuja (Molina, 1782) (Carnivora: Mustelidae).

Type locality: Proximities of Sierra Grande (41 29.3'S; $65^{\circ} 21.2^{\prime} \mathrm{W}$ ), Río Negro province, Argentina. 
Other locality: Proximities of Istmo Ameghino (42 $\left.28.5^{\prime} \mathrm{S} ; 64^{\circ} 41.4^{\prime} \mathrm{W}\right)$, Península Valdés, Chubut province, Argentina.

Site of infection: Subcutaneous tissue of hind legs.

Prevalence and intensity of infection: One out of two Lesser Grisons from Río Negro infected with two males and four females. One out of two Lesser Grisons from Chubut infected with one female.

Type specimens: Holotype male, MLP-He 7737; paratype male, paratypes female (2 anterior fragments and 1 posterior fragment, and two heads and two tails in SEM samples), MLP-He 7738 and, voucher female, MLP-He 7739.

Host specimens deposited: CEVEC-1099 and CEVEC-1105.

Etymology. The specific epithet is dedicated to Rafael S. Lorenzo, Park Ranger of the Administración de Parques Nacionales of Argentina, who works at the Reserva Natural de la Defensa Punta Buenos Aires at Península Valdés and collected the Lesser Grison specimens.

ZooBank access: http://zoobank.org/ References/61D3017D-A30F-4ACE-AB47CE4D54587541

\section{Remarks}

These specimens belong to the family Filariidae, subfamily Filariinae which are large parasites of subcutaneous tissues of mammals, with the vulva markedly anterior to nerve ring; oral opening not surrounded by cuticularized spines, esophagus long and divided, tail long, spicules markedly different in size and structure, and male with numerous caudal papillae. Within this family these specimens can be assigned to the genus Filaria which is characterized by a reduced buccal cavity, a cuticular ring on the anterior end of the esophagus, and the vulva besides the oral opening (Anderson \& Bain 1977).
At present, it is considered that the genus comprises 12 valid species inhabiting carnivores, rodents, artiodactyls and hyracoids. Within the Carnivora, Mustelidae and Mephitidae are the main hosts, and in a much lesser degree Felidae (Table I) (e.g., Ortlepp 1937, Freitas \& Lent 1937, Chandler 1947, Chabaud \& Rousselot 1956, Anderson 1960, Tadros 1964, Keppner 1969, Chabaud et al. 1978, Chabaud \& Mohammad 1989, Otranto et al. 2007, Torres et al. 2016). No new species have been described since 1989. Some authors (e.g., Caballero 1948, Anderson 1960) preferred to consider the species published until 1960 as variations of the type species. However Chabaud \& Mohammad (1989) rather upheld the idea of the plurality of species, supported by the examination of a great amount of material from different hosts; at the time that stated that one of the main characters for differentiating species is the morphology of the preesophageal ring.

Based on thischaracter, ourspecimens, which possess a mushroom shaped preesophageal ring, can be easily differentiated from the eight species found in the Old World: Filaria martis, Filaria hyracis (Ortlepp, 1937), Filaria cephalophi Chabaud \& Rousselot, 1956, Filaria russelli Tadros, 1964, Filaria bakerhugoti Chabaud \& Mohammad, 1989, Filaria latala Chabaud \& Mohammad, 1989, Filaria melis Chabaud \& Mohammad, 1989 and Filaria versterae Chabaud \& Mohammad, 1989. The four remaining species are Filaria texensis Chandler, 1947 and Filaria taxideae Keppner, 1969 from USA, F. carvalhoi from Brazil, and F. conepati from Argentina, all parasites of Mephitidae and/or Mustelidae. Filaria texensis was considered as synonym of F. carvalhoi by Anderson (1960), whereas F. conepati was also proposed as synonym of $F$. carvalhoi by Anderson (1960) and Chabaud \& Mohammad (1989). 


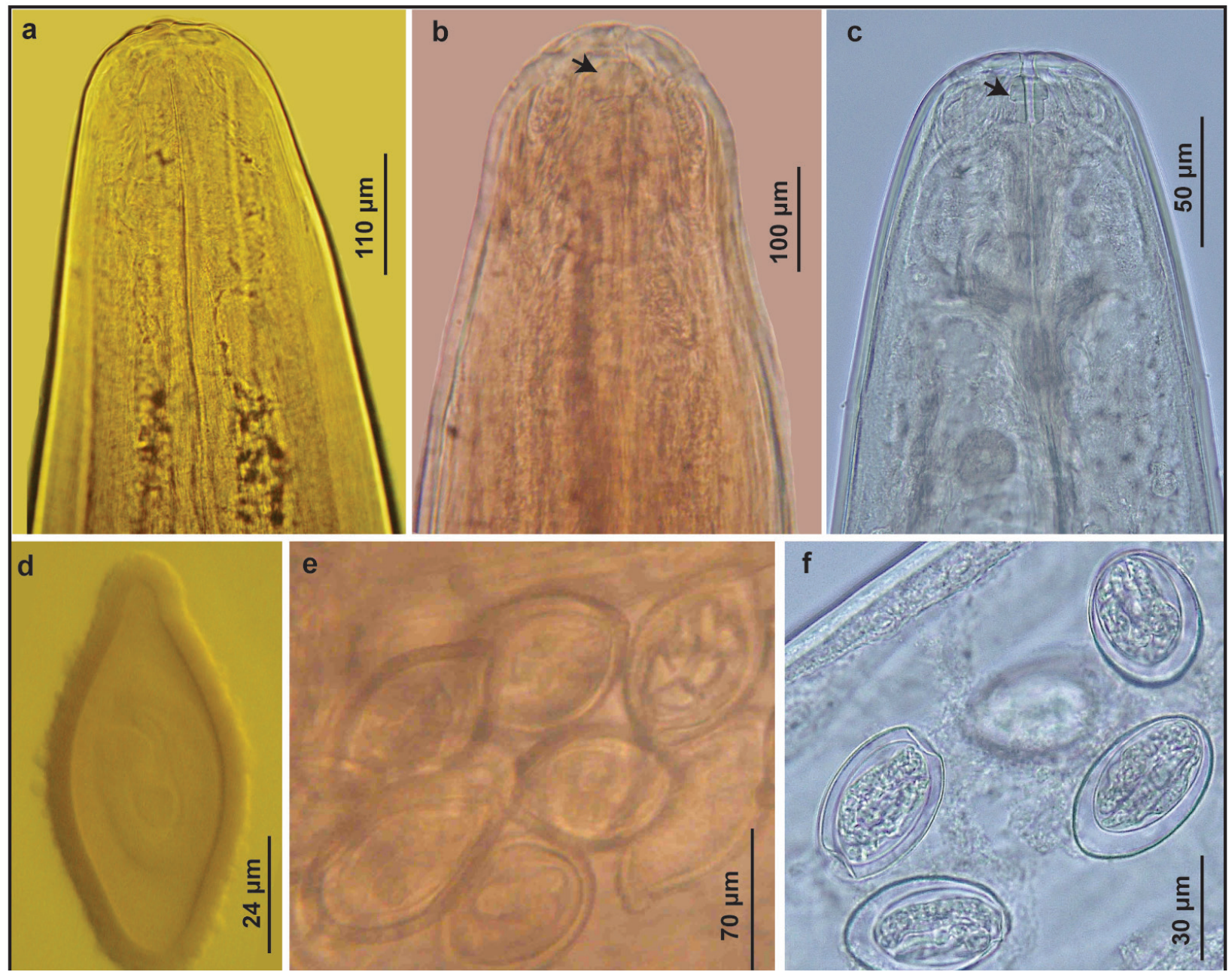

Figure 3. Photographs comparing anterior ends and shape of eggs of South American species. (a, d) Filaria carvalhoi Freitas and \& Lent, 1937, no preesophageal ring, eggs lemon shaped and thick shelled. (b, e) Filaria conepati Schuurmans-Stekhoven, 1952, preesophageal ring (indicated by arrow), with anterior part elliptical and posterior one shorter and stout, eggs lemon shaped and thick shelled. (c, f) Filaria lorenzo n. sp., preesophageal ring (indicated by arrow) with distal part semispherical and proximal one cylindrical, of about same length , eggs elliptical and thin shelled.

A preesophageal ring is not mentioned nor illustrated in the descriptions of Filaria carvalhoi and F. texensis, differentiating these two species from the specimens studied herein but also from the remaining species of Filaria. The lack of a preesophageal ring in F. carvalhoi could be confirmed herein through the observation of photographs taken on the type material (Fig. 3a). Filaria taxideae shares with our specimens the presence of a preesophageal ring. It strongly resembles the new species by the shape of the ring, but differs from it by having a cervical cuticular inflation and a pair of lateral alae (absent in the new species); by the ornamentation of the female tail, consisting in an apical double tip plus 8-10 spaced tubercles (vs. 15-20 subequal tubercles), and by having a pair of adcloacal papillae (absent in our specimens).

Our specimens also differ from the species described as F. conepati. The indirect observation (through photographs) of types of F. conepati 
revealed the presence of a preesophageal ring (Fig. 3b), with anterior part elliptical and posterior one shorter and stout. It is worth noting that such structure was not mentioned nor illustrated in the original description. The shape of the ring of $F$. conepati is different from that of our specimens (composed of an anterior semispherical portion followed by a posterior cylindrical portion of about the same length). Additional differences lie in the shape of the eggs, which in F. conepati are lemon shaped and thick shelled, whereas in our specimens the eggs are elliptical and thin shelled (Fig. 3e, 3f). Finally, the males of the new species were characterized by only eight pairs of caudal papillae, differing from the remaining species in the genus which usually possess nine pairs. The above pointed differences with respect to the existing species in the genus lead us to consider our specimens as belonging to a new species which is named Filaria lorenzo n. sp.

\section{DISCUSSION}

Our results extend the taxonomy of Filaria and comprise the first report of a species of the genus in Patagonia, and the first report of a filarioid nematode for a mustelid in Argentina. The examination, although indirect, of the types of F. conepati and F. carvalhoi allows us to corroborate the existence of differences between these two species: notably, the absence of a preesophageal ring in $F$. carvalhoi and the presence of such a structure in $F$. conepati. This is an important difference allowing us to refute the synonymy of F. carvalhoi and F. conepati proposed by Anderson (1960) and Chabaud \& Mohammad (1989).

According to Chabaud \& Mohammad (1989) the more significant morphological characters in differentiating species of Filaria are: the morphology of the preesophagal ring, the caudal extremity of the female, the caudal alae and symmetry of caudal papillae in the male, and the morphology of the eggs. However, it has to be noted that females with two different morphologies of tail tip (e.g. smooth or mamillated) were repeatedly observed in $F$. martis (Chandler 1947, Anderson 1960, Otranto et al. 2007) as well as in F. texensis and F. carvalhoi (Chandler 1947, Anderson 1960), which means that the value of the female caudal end as a specific character should be relativized.

\section{Acknowledgments}

The authors thank Rafael Lorenzo and Gustavo Pazos for collecting the hosts, Patricia Sarmiento (Servicio de Microscopía Electrónica de Barrido, FCNyM, UNLP, La Plata) for producing the SEM photographs, and the curators of the Helminthological Collections: Marcelo Knoff (Instituto Oswaldo Cruz) and Geraldine Ramallo (Fundación Miguel Lillo) for sending us the photographs of type material. To Néstor J. Cazzaniga for his advice on the naming of the species. To Analía L. Giménez for helping us with the taxonomy of phyllostomid bats. Present study was partially funded by Agencia Nacional de Promoción Científica y Tecnológica (PICT 2019-00569). Field trips were partially funded by the Proyecto de Unidad Ejecutora (PUE) 22920160100044 CO granted to Instituto Patagónico para el Estudio de los Ecosistemas Continentales- CONICET, Argentina, and by the Programa Península Valdés (PROPEVA) project of the Universidad Nacional de la Patagonia San Juan Bosco. Collecting permits were obtained from the Dirección de Fauna y Flora Silvestre del Chubut and Área Natural Protegida Península Valdés and Secretaría de Ambiente y Desarrollo Sustentable de la Provincia de Río Negro.

\section{REFERENCES}

ANDERSON RC. 1960. A study of Filaria martis Gmelin, 1790 from Martes foina and Pedetes caffer. Can J Zool 38: 157-167.

ANDERSON RC \& BAIN O. 1977. Keys to genera of the Order Spirurida. Part 3. Diplotriaenoidea, Aproctoidea and Filarioidea. In: Anderson RC, Chabaud AG \& Willmott S (Eds), ClH keys to the nematode parasites of vertebrates. 
Commonwealth Agricultural Bureaux, Farnham Royal, Bucks, England, p. 59-116.

CABALLERO E. 1948. Filaria martis Gmelin, 1790 en mamíferos de Nuevo León y consideraciones sobre las especies del género Filaria Müller, 1787. Rev Soc Mex Hist Nat 9: 257-261.

CHABAUD AG, LANDAU I \& PETIT G. 1978. Deux filaires de céphalophes au Gabon. Ann Parasitol Hum Comp 53: 285-290.

CHABAUD AG \& MOHAMMAD MK. 1989. Le genre Filaria Gmelin, 1790. Description de quatre espèces nouvelles. Bull Mus Hist Nat, Paris, 4e sér 11: 47-59.

CHABAUD AG \& ROUSSELOT R. 1956. Sur quelques filaries d'Afrique Équatoriale. Ann Parasitol Hum Comp 31: 53-98.

CHANDLER AC. 1947. The species of the genus Filaria Mueller, 1787, s. str. J Parasitol 33: 449-452.

CHÉBEZ JC, PARDIÑAS U \& TETA P. 2014. Mamíferos Terrestres. Patagonia Sur de Argentina y Chile. Vázquez Mazzini, Buenos Aires, p. 207.

CHITWOOD BC. 1933. A note on the status of Vestibulosetaria Vogel and Gabaldon, 1932. Proc Helminthol Soc Wash 19: 253.

CORRÊA P, BUENO C, VIEIRA FM \& MUNIZ-PEREIRA LC. 2016. Helminth parasites of Galictis cuja (Carnivora, Mustelidae), from localities in the Atlantic Forest of Brazil. Braz J Vet Parasitol, Jaboticaba 25: 407-413.

FREITAS JFT \& LENT H. 1937. Segunda especie do genero Filaria Mueller, 1787, s. str. Mem Inst Oswaldo Cruz 32: 423-427.

GIBBONS LM. 2010. Keys to the Nematode Parasites of Vertebrates. Supplementary Volume, First edition, CAB International, Cambridge, UK, 416 p.

GOMES DC, CRUZ RP, VICENTE JJ \& PINTO RM. 2003. Nematode parasites of marsupials and small rodents from the Brazilian Atlantic Forest in the State of Rio de Janeiro, Brazil. Rev Bras Zool 20: 699-707.

GRIEDER H. 1937. Seltene Nutriaparasiten. Schweizer Archiv für Tierheilkunde SAT 79: 520-525.

GRIEDER. H. 1938. Filaridae, Filariosis und Mikrofilariosis bei verschiedenen Säugetieren. Schweizer Archiv für Tierheilkunde SAT 80: 485-490.

GUERRERO R, MARTIN C \& GARDNER SL. 2002. New and Known Species of Litomosoides (Nematoda: Filarioidea): Important Adult and Larval Characters and Taxonomic Changes. Comp Parasitol 69: 177-195.
KEPPNER EJ. 1969. Filaria taxideae n. sp. (Filarioidea: Filariidae) from the Badger, Taxidea taxus taxus from Wyoming. Trans Amer Microsc Soc 88: 581-588.

LARIVIĖRE S \& JENNINGS AP. 2009. Family Mustelidae (Weasels and relatives). In: Wilson DE \& Mittermeir RA (Eds), Handbook of the Mammals of the World. Lynx edicions, Barcelona, p. 564-656.

MAZZA S. 1928. Filarídeo n. sp. de la cavidad peritonal de la rata de los cañaverales de Tabacal, Salta. Reunión de la Sociedad Argentina de Patología Regional del Norte, p. 628-632.

MOLEÓN MS, KINSELLA JM, MORENO PG, DEL VALLE FERREYRA H, PEREIRA J, PÍA M \& BELDOMENICO PM. 2015. New hosts and localities for helminths of carnivores in Argentina. Zootaxa 4057: 106-114.

MOLIN R. 1858. Versuch einer Monographie der Filarien (Mit 2 Tafeln.). Akad der Wissenschaften 1: 365-462.

NOTARNICOLA J, DIGIANI MC \& LÓPEZ PM. 2010. Redescriptions of the nematodes Litomosoides patersoni (Mazza, 1928) (Onchocercidae) and Stilestrongylus stilesi Freitas, Lent, and Almeida, 1937 (Heligmonellidae) parasites of Holochilus chacarius (Rodentia, Cricetidae) from Salta, Argentina. J Parasitol 96: 933-1001.

ORTLEPP RJ. 1937. South African helminths. Part I. Onderstepoort J Vet Res 9: 311-336.

OTRANTO D, LIA RP, CANTACESSI C, BIANTI E, TRAVERSA D \& GIANNETTO S. 2007. Filaria martis Gmelin 1790 (Spirurida, Filariidae) affecting beech marten (Martes foina): morphological description and molecular characterisation of the cytochrome oxidase c subunit I. Parasitol Res 101: 877-883.

PREVOSTI FJ \& TRAVAINI A. 2005. New records of Galictis cuja (Molina, 1782) (Carnivora, Mustelidae) in Southern Patagonia. Mamm Biol 70: 317-320.

SCHUURMANS-STEKHOVEN JH. 1952. Nemátodos parasitarios de anfibios, pájaros y mamíferos de la República Argentina. Acta Zool Lilloana 10: 315-400.

TADROS G. 1964. On Filaria martis Gmelin, 1790, newly recorded from the leopard with the description of a new species of the genus Filaria Mueller, 1787. J Helminthol 38: $125-128$.

TORRES J, MIQUEL J, FOURNIER-CHAMBRILLON C, ANDRÉ A, URRA MAYA F, GUIRALDA CARRERA G \& FOURNIER P. 2016. First report of Filaria martis Gmelin, 1790 in the European mink, Mustela lutreola (Linnaeus, 1761). Parasitol Res 115: 2499-24503. 
VIEIRA FM, LUQUE JL \& MUNIZ-PEREIRA LC. 2008. Checklist of helminth parasites in wild carnivore mammals from Brazil. Zootaxa 1721: 1-23.

YENSEN E \& TARIFA T. 2003. Galictis cuja. Mamm Species 728: $1-8$.

\section{How to cite}

BAGNATO E, D`AGOSTINO RL, UDRIZAR SAUTHIER DE \& DIGIANI MC. 2022. New species of Filaria (Nematoda: Filariidae) in the Lesser Grison Galictis cuja (Molina) (Carnivora: Mustelidae) from northern Patagonia, Argentina and comments about the South American species of the genus. An Acad Bras Cienc 94: e20200099. DOI 10.1590/00013765202120200099.

Manuscript received on January 20, 2020;

accepted for publication on August 13, 2020

\section{ESTEFANÍA BAGNATO $0^{1,2}$}

https://orcid.org/0000-0002-7169-9125

ROMINA L. D'AGOSTINO

https://orcid.org/0000-0002-1300-4786

DANIEL E. UDRIZAR SAUTHIER ${ }^{3,4}$

https://orcid.org/0000-0002-3195-9893

MARÍA C. DIGIANI ${ }^{5}$

https://orcid.org/0000-0002-1626-9309
${ }^{1}$ Universidad Nacional de la Patagonia San Juan Bosco, Laboratorio de Investigaciones en Evolución y Biodiversidad (LIEB), Facultad de Ciencias Naturales y Ciencias de la Salud, Ruta Nacional N²59, 16,4 Km, 9200, Esquel, Chubut, Argentina ${ }^{2}$ Centro de Investigación Esquel de Montaña y Estepa Patagónica (CIEMEP)-Consejo Nacional de Investigaciones Científicas y Técnicas (CONICET)-UNPSJB, General Roca 780, 9200, Esquel, Chubut, Argentina ${ }^{3}$ Grupo de Estudio de Mamíferos Terrestres (GEMTE), Instituto Patagónico Para el Estudio de los Ecosistemas Continentales (IPEEC-CONICET), Boulevard Brown 2915, 9120, Puerto Madryn, Chubut, Argentina

${ }^{4}$ Universidad Nacional de la Patagonia San Juan Bosco (UNPSJB), Boulevard Almirante Brown 3051, 9120, Puerto Madryn, Chubut, Argentina

${ }^{5}$ Universidad Nacional de La Plata, CONICET, División Zoología Invertebrados, Facultad de Ciencias Naturales y Museo, Paseo del Bosque s/n, 1900, La Plata, Buenos Aires, Argentina

Correspondence to: Estefanía Bagnato

E-mail:ebagnato@comahue-conicet.gob.ar

\section{Author contributions}

Estefanía Bagnato: processed the samples, studied and described the nematodes, wrote the manuscript, made the drawings and plates. Romina L. D'Agostino: samples collection and processing. Daniel E. Udrizar Sauthier: samples collection. M. Celina Digiani: Helped in studying the nematodes, writing the manuscript, managed the request of type material, supervised the work.

\section{(cc) BY}

